\title{
Seasonal variations of concentrations and optical properties of water soluble HULIS collected in urban environments
}

\author{
C. Baduel, D. Voisin, and J.-L. Jaffrezo \\ Université Joseph Fourier - Grenoble 1/CNRS-INSU, Laboratoire de Glaciologie et Géophysique de l'Environnement, \\ rue Molière, 38402 Saint-Martin-d'Hères, France
}

Received: 20 August 2009 - Published in Atmos. Chem. Phys. Discuss.: 14 October 2009

Revised: 13 April 2010 - Accepted: 28 April 2010 - Published: 3 May 2010

\begin{abstract}
Major contributors to the organic aerosol include water-soluble macromolecular compounds (e.g. HULIS $\mathrm{WS}_{\mathrm{S}}$ : Water Soluble Humic LIke Substances). The nature and sources of HULIS ${ }_{W S}$ are still largely unknown. This work is based on a monitoring in six different French cities performed during summer and winter seasons. HULIS ${ }_{\mathrm{WS}}$ analysis was performed with a selective method of extraction complemented by carbon quantification. UV spectroscopy was also applied for their chemical characterisation. HULIS $\mathrm{WS}_{\mathrm{W}}$ carbon represent an important contribution to the organic aerosol mass in summer and winter, as it accounts for 12 $22 \%$ of Organic Carbon and 34-40\% of Water Soluble Organic Carbon. We found strong differences in the optical properties (specific absorbance at 250,272, $280 \mathrm{~nm}$ and E2/E3 ratio) and therefore in the chemical structure between HULIS ${ }_{W S}$ from samples of summer- and wintertime. These differences highlight different processes responsible for emissions and formation of HULIS $\mathrm{WS}_{\mathrm{WS}}$ according to the season, namely biomass burning in winter, and secondary processes in summer. Specific absorbance can also be considered as a rapid and useful indicator of the origin of HULIS $_{W S}$ in urban environment.
\end{abstract}

\section{Introduction}

The composition of the organic fraction of atmospheric aerosols and the respective contributions of primary and secondary sources are still poorly known, in part due to the considerable number of chemical species present in the particles.

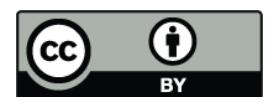

Correspondence to: D. Voisin (didier.voisin@ujf-grenoble.fr)
During the last years it was shown that HUmic LIke Substances (HULIS, i.e. polyacidic macromolecular species), are important contributors to the mass of the organic aerosol in rural, urban, marine, and biomass burning aerosol (Salma et al., 2007). The water soluble fraction of HULIS (HULIS ${ }_{\mathrm{WS}}$ ) most likely influences the hygroscopicity and the CCN ability of particles (Asa-Awuku et al., 2008; Dinar et al., 2006; Hatch et al., 2008; Salma et al., 2008) as well as their optical properties (Dinar et al., 2008). Currently, atmospheric HULIS research is hindered by the lack of a unified method for the analysis of these compounds and by a lack of knowledge on their sources (Graber and Rudich, 2006, and references therein). Recently, Feczko et al. (2007), showed a seasonal cycle of HULIS concentrations for six background sites, with one maximum in summer and/or one in winter. These variations have been seen as due to changes in either the sources of HULIS, or their formation processes, assuming that HULIS consist in a mixture of primary emissions and secondary products of various origins. In this paper, we investigate the temporal and structural variation of the HULIS $_{\mathrm{WS}}$ fraction collected in urban environments.

\section{Experimental section}

\subsection{Sampling}

Aerosol samples were collected in the urban background of 6 large French cities: Grenoble, Strasbourg, Lille, Paris, Toulouse, and Marseilles. Samples were collected on quartz fiber filters (150 mm diameter, Whatman, Q-MA) using DA-80 high volume samplers (DIGITEL), operating at $30 \mathrm{~m}^{3} \mathrm{~h}^{-1}$. The filters were prepared before collection by firing them during $2 \mathrm{~h}$ at $600^{\circ} \mathrm{C}$. Sampling duration in

Published by Copernicus Publications on behalf of the European Geosciences Union. 
Marseilles was based on a day/night pattern, with $12 \mathrm{~h}$ sampling for a total period of 14 days during summer 2008 . The sampling for all other locations took place daily once or twice a week, for periods of several months in summer 2008 and/or in winter 2008. Sampling periods and numbers of samples are reported in Table 1. More details about theses different campaigns can be found elsewhere (El Haddad et al., 2009; Pissot et al., 2010). Additional samples were collected in the small town of Chamonix, located in a valley of the French Alps (Aymoz et al., 2007). The sampling took place for a period of 10 days in winter 2007 (10 to 19 December 2007) in a suburban location. Sampling duration was based on a day/night pattern, with $12 \mathrm{~h}$ sampling. $\mathrm{PM}_{10}$ samples were collected on quartz fiber filters (Whatman ${ }^{\circledR}$, $150 \mathrm{~mm}$ diameter) with a high-volume sampler (Tisch Andersen) at a flow rate of $30 \mathrm{~m}^{3} \mathrm{~h}^{-1}$. More details about sampling can be found elsewhere (Baduel et al., 2009). Finally, some samples are coming from a tunnel study conducted in Marseilles in spring 2008. They were also collected with a similar protocol, except for a much shorter sampling time. After sampling, all filters were wrapped in aluminium foils, sealed in polyethylene bags and stored frozen until further analysis.

\subsection{Analysis}

These atmospheric samples are analyzed for EC/OC (Elemental and Organic Carbon), WSOC (Water Soluble Organic Carbon), and HULIS ${ }_{W S}$ concentrations. EC/OC concentrations are determined by Thermo-Optical Transmission (TOT) method on a Sunset Lab analyzer (Aymoz et al., 2007). We are using the newly developed EUSAAR2 temperature program (Cavalli et al., 2010). It includes temperature steps up from 200 to $650{ }^{\circ} \mathrm{C}$ for the analysis of OC in $100 \% \mathrm{He}$, and up from 500 to $700^{\circ} \mathrm{C}$ for the analysis of $\mathrm{EC}$ in $98 \% \mathrm{He}+2 \%$ $\mathrm{O}_{2}$. Automatic split time was always used for the distinction between EC and pyrolyzed OC. We analyzed fractions of $1.5 \mathrm{~cm}^{2}$ of the filters, without any preparation.

For WSOC determination, $17-20 \mathrm{~cm}^{2}$ of filter are extracted during $30 \mathrm{~min}$ in $12 \mathrm{~mL}$ of organic free water (Elgastat $($ ). The surfaces extracted are adapted according to the OC concentrations measured in each sample. The extracts are filtered with Acrodisk filters (Pall Gellman®, $0.22 \mu \mathrm{m}$ porosity) to remove any particles in suspension. WSOC is quantified with a TOC analyser (Shimadzu TOC$\mathrm{VCPH} / \mathrm{CPN}$ ) by catalytic burning at $680^{\circ} \mathrm{C}$ in oxygen followed by non dispersive infrared detection of the evolved $\mathrm{CO}_{2}$.

The water soluble HULIS fraction is analyzed according to a protocol described in detail elsewhere (Baduel et al., 2009). Briefly, the water soluble fractions obtained from aerosol samples (see paragraph above) are passed through a weak anion exchange resin (GE Healthcare ${ }^{\circledR}$, HiTrap ${ }^{\text {TM }}$ DEAE FF, $0.7 \mathrm{~cm} \mathrm{ID} \times 2.5 \mathrm{~cm}$ length) without any pre-treatment. After this concentration step, the organic matter adsorbed is washed with $12 \mathrm{~mL}$ of a solution of $\mathrm{NaOH}$
$0.04 \mathrm{M}$ (J. T. Baker $®$, pro analysis) to remove neutral components, hydrophobic bases, inorganic anion, mono- and diacids initially retained in the resin. Finally, HULIS $S_{W S}$ are quickly eluted in a single broad peak using $4 \mathrm{~mL}$ of a high ionic strength solution of $\mathrm{NaCl} 1 \mathrm{M}$ (Normapur ${ }^{\circledR}$ ). All flow rates are set at $1.0 \mathrm{~mL} \mathrm{~min}^{-1}$. In this case, HULIS ${ }_{\mathrm{WS}}$ are operational defined as polyacidic compounds. UV-Vis absorption spectra are measured on-line after the extraction system, using a diode array detector (Dionex UV-VIS 340U), and recorded in the range $220-550 \mathrm{~nm}$. The HULIS ${ }_{W S}$ fraction is subsequently collected manually and the carbon content is analyzed with the same TOC analyser used for WSOC determination. Aliquots of the same filter extracts were analysed with Ionic Chromatography (IC) following the method described in Ricard et al. (2002). Cations $\left(\mathrm{NH}_{4}^{+}, \mathrm{K}^{+}, \mathrm{Mg}^{2+}\right.$, $\mathrm{Ca}^{2+}$ ) were determined with a Dionex 100 IC, equipped with a CS12 column. Sodium could not be determined, due to high blank values coming from the filters quartz matrix. Inorganic anions $\left(\mathrm{Cl}^{-}, \mathrm{NO}_{3}^{-}, \mathrm{SO}_{4}^{2-}\right)$ and dicarboxylic acids (oxalate, glutarate, malonate, succinate and malate) were determined with a dionex DX500 equipped with an AS11 column.

\section{Results and discussion}

\subsection{Atmospheric concentrations}

The average concentrations and contributions of the HULIS $_{W S}$ fractions for all campaigns are presented in Table 1. The concurrent measurements of concentrations for OC, WSOC, and HULIS ${ }_{W S}$ allow several observations. Figure 1 shows one year of HULIS ${ }_{W S}$, OC and WSOC in Grenoble. HULIS ${ }_{W S}$ follows the same seasonal trend as OC and WSOC, with a clear maximum in winter and minimum in summer. In summer, concentrations measured in Grenoble, Marseille and Toulouse are mostly between 0.2 and $1 \mu \mathrm{g} \mathrm{m}^{-3}$ (average 0.63, 0.59 and $0.48 \mu \mathrm{g} \mathrm{C} \mathrm{m}^{3}$ respectively). In winter, in each site (Grenoble, Strasbourg; Lille, Chamonix and Paris), the spread in measured concentrations is higher, with values between 0.2 and $3 \mu \mathrm{g} \mathrm{m}^{-3}$ (averages between 1.00 and $2.11 \mu \mathrm{g} \mathrm{m}^{3}$ ). The higher dispersion of the winter values, together with the very similar low values across the year might be due to dispersion phenomena, much more sensitive in winter when temperature inversion are most common.

Seasonal variations of HULIS $\mathrm{WS}_{\mathrm{S}}$ in urban environments are relatively scarce to compare with. Limbeck et al. (2005) observed a similar seasonality in Vienna, Austria, with concentrations varying from $\sim 0.3 \mu \mathrm{g} \mathrm{C} \mathrm{m}{ }^{-3}$ in summer to $\sim 1.5 \mu \mathrm{g} \mathrm{C} \mathrm{m}^{-3}$ in winter. Feczko et al. (2007) and Duarte et al. (2007) found a similar seasonal variation in Aveiro, Portugal, with concentrations varying from 0.3 to $0.9 \mu \mathrm{g} \mathrm{C} \mathrm{m}{ }^{-3}$ and from 0.6 to $2.33 \mu \mathrm{g} \mathrm{C} \mathrm{m}^{-3}$ respectively between summer and winter. Krivácsy et al. (2008) also found similar seasonal variations in Auckland and Christchurch, New Zealand 
Table 1. Variations of mean concentration of Water Soluble HULIS (in $\mu \mathrm{g} \mathrm{C} \mathrm{m}^{-3}$ ) with standard deviation and its contribution to WSOC and OC aerosol fractions for each sample set.

\begin{tabular}{|c|c|c|c|c|c|c|}
\hline \multirow[t]{2}{*}{ Season } & \multirow[t]{2}{*}{$\begin{array}{l}\text { Location and sam- } \\
\text { pling month }\end{array}$} & \multirow[t]{2}{*}{$\begin{array}{l}\text { Number of } \\
\text { samples }\end{array}$} & \multicolumn{2}{|c|}{$\begin{array}{l}\text { HULIS }_{W S} \text { concentration } \\
\left(\mu \mathrm{g} \mathrm{C} \mathrm{m}^{-3}\right)\end{array}$} & \multicolumn{2}{|c|}{$\begin{array}{l}\text { HULIS } \\
(\%)\end{array}$} \\
\hline & & & Average & $\min -\max$ & WSOC & $\mathrm{OC}$ \\
\hline \multirow[t]{4}{*}{$\begin{array}{l}\text { Urban environment } \\
\text { during cold season }\end{array}$} & $\begin{array}{l}\text { Paris } 08 \text { (January to } \\
\text { February) }\end{array}$ & 16 & $1.08 \pm 0.86$ & $0.34-2.25$ & $34.1 \pm 9.0$ & $14.6 \pm 3.2$ \\
\hline & $\begin{array}{l}\text { Lille } 08 \text { (January to } \\
\text { February) }\end{array}$ & 10 & $0.85 \pm 0.41$ & $0.39-1.60$ & $40.3 \pm 10.0$ & $16.0 \pm 5.1$ \\
\hline & $\begin{array}{l}\text { Strasbourg } 08 \text { (Jan- } \\
\text { uary to February) }\end{array}$ & 16 & $1.17 \pm 0.80$ & $0.42-2.57$ & $38.3 \pm 5.4$ & $22.7 \pm 6.8$ \\
\hline & $\begin{array}{l}\text { Grenoble } 08 \\
\text { (November to } \\
\text { February) }\end{array}$ & 69 & $1.38 \pm 0.71$ & $0.20-3.12$ & $39.5 \pm 7.6$ & $16.4 \pm 6.1$ \\
\hline $\begin{array}{l}\text { Biomass burning } \\
\text { background }\end{array}$ & $\begin{array}{l}\text { Chamonix } 07 \\
\text { (December) }\end{array}$ & 16 & $1.47 \pm 0.95$ & $0.37-4.36$ & $23.4 \pm 3.1$ & $12.7 \pm 1.8$ \\
\hline \multirow{3}{*}{$\begin{array}{l}\text { Urban environment } \\
\text { during summer }\end{array}$} & Marseilles 08 (July) & 28 & $0.68 \pm 0.38$ & $0.22-1.73$ & $28.4 \pm 6.8$ & $14.2 \pm 4.1$ \\
\hline & $\begin{array}{l}\text { Toulouse } 08 \text { (June } \\
\text { to August) }\end{array}$ & 18 & $0.51 \pm 0.30$ & $0.11-1.48$ & $42.7 \pm 10.8$ & $17.3 \pm 5.0$ \\
\hline & $\begin{array}{l}\text { Grenoble } 08 \text { (May } \\
\text { to August) }\end{array}$ & 19 & $0.57 \pm 0.25$ & $0.20-1.06$ & $36.6 \pm 7.6$ & $16.5 \pm 5.5$ \\
\hline \multirow[t]{2}{*}{ Mid season } & $\begin{array}{l}\text { Grenoble } 08 \\
\text { (September to } \\
\text { October) }\end{array}$ & 13 & $0.62 \pm 0.28$ & $0.31-1.27$ & $30.6 \pm 6.5$ & $14.9 \pm 5.6$ \\
\hline & $\begin{array}{l}\text { Grenoble } 08 \\
\text { (March to April) }\end{array}$ & 18 & $0.90 \pm 0.37$ & $0.40-1.62$ & $27.7 \pm 5.7$ & $17.0 \pm 3.7$ \\
\hline
\end{tabular}

with concentrations varying from 0.35 to $2.11 \mu \mathrm{g} \mathrm{C} \mathrm{m}{ }^{-3}$ and from 0.24 to $5.44 \mu \mathrm{g} \mathrm{C} \mathrm{m}^{-3}$ respectively between summer and winter.

The difference in winter enhancement observed between our and previous studies can be partly related to our selective extraction protocol. Indeed, we will show that our samples are strongly impacted by biomass burning emissions, and functionalized aromatic compounds (like phenol, vanillin, syringaldehyde, etc...) are consistently emitted by such sources (Graham et al., 2002). These compounds are associated with the HULIS fraction for the protocol used by Krivácsy et al. (2008), according to Limbeck et al. (2005), and for the protocol used by Duarte et al. (2007), according to Sullivan and Weber (2006) while they are excluded from it in our protocol (Baduel et al., 2009).

Second, the contribution of HULIS ${ }_{W S}$ to WSOC as measured in our study is between $28-43 \%$ and the contribution to $\mathrm{OC}$ is in the range $14-22 \%$, stressing the strong contribution of HULIS $\mathrm{WS}_{\mathrm{WS}}$ to the organic aerosol mass all year long. The HULIS ${ }_{W S}$ contributions in our study are comparable to data obtained with a comparable extraction method for polluted rural background: $24-44 \%$ of WSOC for a yearly study (Decesari et al., 2001).
Finally, rather large concentrations of HULIS ${ }_{\mathrm{WS}}$ are measured in vehicle emissions as compared to HULIS ${ }_{W S}$ concentrations found in urban background in summer. However, in the former case HULIS ${ }_{W S}$ only represent a relatively small fraction of OC due to the important hydrophobic character of freshly emitted organic aerosol in vehicle exhaust (El Haddad et al., 2009).

\subsection{Chemical characterisation}

Just as Humic substances, HULIS consist of poly-conjugated structural elements carrying carboxyl, hydroxyl and carbonyl polar groups (Decesari et al., 2001; Duarte et al., 2008, 2007; Graham et al., 2002; Kiss et al., 2002; Tagliavini et al., 2006). It is largely demonstrated that HULIS present light absorption in the UV-Vis range (Graber and Rudich, 2006). Although the spectra are essentially featureless, with a sharp decrease between 200 and $400 \mathrm{~nm}$, clear shoulders can be seen for HULIS as for fulvic acids in the wavelength region between 250 and $300 \mathrm{~nm}$. This absorption, characteristic of fulvic acids is generally attributed to $\pi-\pi^{*}$ electron transitions in moieties containing $\mathrm{C}=\mathrm{C}$ and $\mathrm{C}=\mathrm{O}$ double bonds (Chin et al., 1994; Peuravuori and Pihlaja, 1997). 

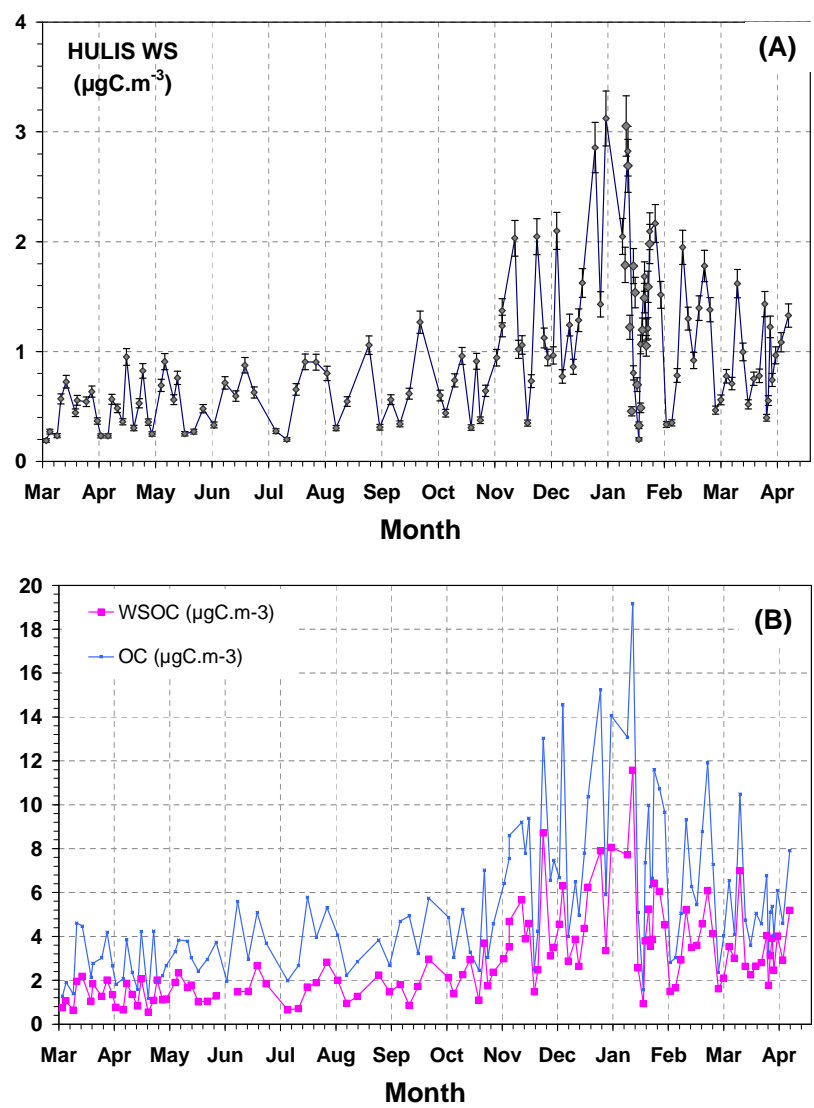

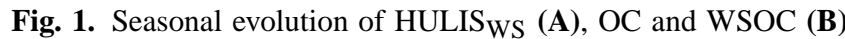
concentrations $\left(\mu \mathrm{gC} \mathrm{m}^{-3}\right)$ in Grenoble.

Following this, many studies on aquatic humic substances have found large correlations between aromaticity and absorbance at various wavelengths $(254,272$ and $280 \mathrm{~nm})$, as for example in Hautala et al. (2000). In particular, absorption between 270 and $280 \mathrm{~nm}$ is often used to represent aromaticity in humic substances because $\pi-\pi^{*}$ electronic transitions of polyenes, benzoic acids, PAHs (with a minimum of 2 to 3 cycles) and aniline derivatives occur in this region and are recurrent structural patterns in humic substances (Chin et al., 1994; Traina et al., 1990). These same structures (except PAHs) have been identified by ${ }^{13} \mathrm{C}-\mathrm{NMR}$ in HULIS $\mathrm{WS}$ (Sannigrahi et al., 2006). Another indicator of aromaticity widely used in aquatic humic substances research ( $\mathrm{Li}$ et al., 2009; Peuravuori and Pihlaja, 1997), and previously applied on HULIS ${ }_{W S}$ (Duarte et al., 2005; Krivácsy et al., 2008) is the ratio (E2/E3) of absorbance at $250 \mathrm{~nm}$ over absorbance at $340 \mathrm{~nm}$, which is strongly correlated with total aromaticity in humic substances and does not depend on carbon measurements. We will thus discuss our spectroscopic measurements (mainly specific absorbance at $254 \mathrm{~nm}$ ) in terms of relative aromaticity in HULIS ${ }_{W S}$ for our different sites and seasons. These are summarized in Table 2.
First, one can see that for the overall sample set obtained in Grenoble in 2008 (the only one covering all seasons), we can observe three different trends, corresponding to samples collected in summer, winter, and mid seasons, respectively. High (respectively low) specific absorbance during the cold (respectively warm) season lead to high (respectively low) slope for the regressions between concentrations and absorbance, with results from mid seasons in-between. Correlations for the regression lines are excellent $\left(r^{2}>0.8\right)$ and values of the average specific absorbance for each season are statistically different, indicating a consistent pattern over each of the data sets. Further, the intercepts are low in each case, an indication that our extraction protocol is efficient in getting rid of any inorganic species absorbing at $250 \mathrm{~nm}$. Second, the Table 2 indicates that all other sample sets follow a similar pattern, with large specific absorbance in the cold season and a much lower one in summer, irrespective of the sampling locations. For each site in summer and winter, regressions between absorbance at any wavelength and concentrations also present excellent correlation coefficients $\left(r^{2}>0.8\right)$, with essentially no difference in correlation coefficients between various sites. Mid season data in Grenoble show a lesser correlation $\left(r^{2}\right.$ between 0.39 and 0.79 depending on wavelength), that might be related with continuous shifts between summer and winter like conditions and sources during the midseason.

\subsection{Characteristics of the combined data sets}

In a second step, samples from the different sites are gathered according to the sampling season and the associated regression lines are plotted in Fig. 3. It shows that the correlations between the concentrations of HULIS ${ }_{\mathrm{WS}}$ and its absorbance at $250 \mathrm{~nm}$ are strongly different between the summer $(n=65)$ and winter $(n=73)$ sample sets. This agrees well with different chemical structures for winter and summertime HULIS $S_{W S}$, which can be related to seasonal differences in emissions and/or formation processes. Moreover, the excellent correlation for each regression shows the stability of the bulk structure of the HULIS ${ }_{W S}$ extracted during these two different periods, with a very low dependency on the specific site.

\subsubsection{Winter}

HULIS $_{\text {WS }}$ collected in winter present a strong absorbance at the wavelength of 250,272 and $280 \mathrm{~nm}$, as well as a smaller E2/E3 ratio, which might be attributed to an important contribution of aromatic structures (Fig. 2). As mentioned above, it is known that biomass combustion processes release aromatic species at high concentration into the atmosphere (Graham et al., 2002). It is proposed that such combustions represent the most probable source of HULIS ${ }_{\mathrm{WS}}$ in urban areas during the burning season (Krivácsy et al., 2008). This is further supported by the correlations between HULIS and 
Table 2. Correlations between TOC $(x, \mu \mathrm{gC})$ and absorbance data at various wavelength $(y, \mathrm{AU})$ for different sample sets from urban environments in summertime and/or in wintertime. In parenthesis is the correlation coefficient. The specific absorbance $\varepsilon\left(\mathrm{cm}^{2} \mathrm{mg}_{\mathrm{C}}^{-1}\right)$ is the average value of the whole sample set for each described site. Uncertainties include standard deviation of the sample set.

\begin{tabular}{|c|c|c|c|c|c|c|c|}
\hline Season & $\begin{array}{l}\text { Location and } \\
\text { sampling month }\end{array}$ & $\begin{array}{l}\text { Number } \\
\text { of } \\
\text { samples }\end{array}$ & $250 \mathrm{~nm}$ & $272 \mathrm{~nm}$ & $280 \mathrm{~nm}$ & $300 \mathrm{~nm}$ & E2/E3 \\
\hline \multirow[t]{4}{*}{$\begin{array}{l}\text { Urban environment } \\
\text { during cold season }\end{array}$} & $\begin{array}{l}\text { Paris (January to } \\
\text { February) }\end{array}$ & 16 & $\begin{array}{l}y=41.0 x-0.5\left(r^{2}=0.99\right) \\
\varepsilon=40.9 \pm 3.2\end{array}$ & $\begin{array}{l}y=28.0+1.15\left(r^{2}=0.99\right) \\
\varepsilon=29.45 \pm 3.0\end{array}$ & $\begin{array}{l}y=25.9 x+1.3\left(r^{2}=0.99\right) \\
\varepsilon=28.0 \pm 2.1\end{array}$ & $\begin{array}{l}y=22.83 x+0.18\left(r^{2}=0.99\right) \\
\varepsilon=2=3.4 \pm 2.01\end{array}$ & $3.23 \pm 0.18$ \\
\hline & $\begin{array}{l}\text { Lille (January to } \\
\text { February) }\end{array}$ & 10 & $\begin{array}{l}y=41.5 x-0.1 \quad\left(r^{2}=0.92\right) \\
\varepsilon=41.5 \pm 6.4\end{array}$ & $\begin{array}{l}y=33.9 x-2.5 \quad\left(r^{2}=0.95\right) \\
\varepsilon=30.1 \pm 4.72\end{array}$ & $\begin{array}{l}y=30.4 x-2.15\left(r^{2}=0.92\right) \\
\varepsilon=27.3 \pm 4.1\end{array}$ & $\begin{array}{l}y=24.8 x-0.1\left(r^{2}=0.89\right) \\
\varepsilon=22.9 \pm 3.8\end{array}$ & $3.47 \pm 0.23$ \\
\hline & $\begin{array}{l}\text { Strasbourg (Decem- } \\
\text { ber to February) }\end{array}$ & 16 & $\begin{array}{l}y=41.3 x-0.7\left(r^{2}=0.98\right) \\
\varepsilon=40.5 \pm 4.8\end{array}$ & $\begin{array}{l}y=28.1 x-0.7\left(r^{2}=0.96\right) \\
\varepsilon=27.7 \pm 3.8\end{array}$ & $\begin{array}{l}y=27.9 x+0.01\left(r^{2}=0.98\right) \\
\varepsilon=26.3 \pm 4.2\end{array}$ & $\begin{array}{l}y=22.5 x-0.1\left(r^{2}=0.96\right) \\
\varepsilon=21.7 \pm 3.6\end{array}$ & $3.29 \pm 0.22$ \\
\hline & $\begin{array}{l}\text { Grenoble (November } \\
\text { to February) }\end{array}$ & 9 & $\begin{array}{l}y=45.9 x+3.1\left(r^{2}=0.94\right) \\
\varepsilon=49.3 \pm 5.9\end{array}$ & $\begin{array}{l}y=35.9 x+0.6\left(r^{2}=0.93\right) \\
\varepsilon=36.7 \pm 4.4\end{array}$ & $\begin{array}{l}y=32.4 x+2.1\left(r^{2}=0.96\right) \\
\varepsilon=34.5 \pm 3.4\end{array}$ & $\begin{array}{l}y=27.3 x+1.9\left(r^{2}=0.93\right) \\
\varepsilon=29.4 \pm 3.6\end{array}$ & $3.14 \pm 0.20$ \\
\hline $\begin{array}{l}\text { Biomass burning } \\
\text { background }\end{array}$ & $\begin{array}{l}\text { Chamonix (Decem- } \\
\text { ber) }\end{array}$ & 16 & $\begin{array}{l}y=58.1 x+0.8\left(r^{2}=0.98\right) \\
\varepsilon=58.9 \pm 6.5\end{array}$ & $\begin{array}{l}y=39.9 x+0.7\left(r^{2}=0.98\right) \\
\varepsilon=41.6 \pm 4.1\end{array}$ & $\begin{array}{l}y=34.07 x+2.0\left(r^{2}=0.98\right) \\
\varepsilon=36.7 \pm 4.1\end{array}$ & $\begin{array}{l}y=32.8 x-0.7\left(r^{2}=0.98\right) \\
\varepsilon=32.4 \pm 3.2\end{array}$ & $2.88 \pm 0.18$ \\
\hline \multirow[t]{3}{*}{$\begin{array}{l}\text { Urban environment } \\
\text { during summer }\end{array}$} & Marseilles (July) & 28 & $\begin{array}{l}y=19.1 x+1.6\left(r^{2}=0.92\right) \\
\varepsilon=22.5 \pm 3.7\end{array}$ & $\begin{array}{l}y=13.7 x+0.13\left(r^{2}=0.91\right) \\
\varepsilon=14.1 \pm 2.3\end{array}$ & $\begin{array}{l}y=12.4 x+0.1\left(r^{2}=0.91\right) \\
\varepsilon=12.7 \pm 2.1\end{array}$ & $\begin{array}{l}y=10.8 x\left(r^{2}=0.92\right) \\
\varepsilon=10.8 \pm 1.8\end{array}$ & $5.90 \pm 0.85$ \\
\hline & $\begin{array}{l}\text { Toulouse (June to } \\
\text { August) }\end{array}$ & 18 & $\begin{array}{l}y=15.4 x+2.5\left(r^{2}=0.88\right) \\
\varepsilon=21.6 \pm 4.7\end{array}$ & $\begin{array}{l}y=13.2 x+2.3\left(r^{2}=0.94\right) \\
\varepsilon=18.8 \pm 2.4\end{array}$ & $\begin{array}{l}y=12.9 x+1.8\left(r^{2}=0.94\right) \\
\varepsilon=17.2 \pm 2.4\end{array}$ & $\begin{array}{l}y=9.8 x+1.76\left(r^{2}=0.85\right) \\
\varepsilon=14.3 \pm 3.0\end{array}$ & $4.59 \pm 0.33$ \\
\hline & $\begin{array}{l}\text { Grenoble (May to } \\
\text { August) }\end{array}$ & 19 & $\begin{array}{l}y=19.9 x+1.6\left(r^{2}=0.84\right) \\
\varepsilon=22.8 \pm 4.7\end{array}$ & $\begin{array}{l}y=15.3 x+0.9\left(r^{2}=0.83\right) \\
\varepsilon=17.3 \pm 3.6\end{array}$ & $\begin{array}{l}y=14.5 x+1.4\left(r^{2}=0.84\right) \\
\varepsilon=16.9 \pm 2.8\end{array}$ & $\begin{array}{l}y=12.9 x+0.9\left(r^{2}=0.87\right) \\
\varepsilon=14.6 \pm 3.1\end{array}$ & $4.55 \pm 0.33$ \\
\hline \multirow[t]{2}{*}{ Mid season } & $\begin{array}{l}\text { Grenoble (Septtember } \\
\text { to October) }\end{array}$ & 13 & $\begin{array}{l}y=36.9+1.3\left(r^{2}=0.79\right) \\
\varepsilon=39.14 \pm 9.8\end{array}$ & $\begin{array}{l}y=28.5 x+0.6\left(r^{2}=0.78\right) \\
\varepsilon=29.5 \pm 7.4\end{array}$ & $\begin{array}{l}y=24.4 x+2.8\left(r^{2}=0.69\right) \\
\varepsilon=27.1 \pm 6.4\end{array}$ & $\begin{array}{l}y=13.9 x+4.3\left(r^{2}=0.39\right) \\
\varepsilon=22.8 \pm 12.9\end{array}$ & $3.59 \pm 0.31$ \\
\hline & $\begin{array}{l}\text { Grenoble (March to } \\
\text { April) }\end{array}$ & 41 & $\begin{array}{l}y=26.9 x+6.1\left(r^{2}=0.54\right) \\
\varepsilon=38.1 \pm 9.9\end{array}$ & $\begin{array}{l}y=20.83 x+4.52 \\
\left(r^{2}=0.62\right) \\
\varepsilon=29 \pm 7.5\end{array}$ & $\begin{array}{l}y=21.9 x+3.3\left(r^{2}=0.60\right) \\
\varepsilon=28.1 \pm 7.2\end{array}$ & $\begin{array}{l}y=16.3 x+3.6\left(r^{2}=0.67\right) \\
\varepsilon=23.1 \pm 6.3\end{array}$ & $3.35 \pm 0.32$ \\
\hline
\end{tabular}

biomass burning tracers such as levoglucosan, dehydroabietic acid, and fine potassium (Feczko et al., 2007; Krivácsy et al., 2008; Mayol-Bracero et al., 2002). These results are also in good agreement with recent chemical characterisation studies of WSOC from biomass burning source (Duarte et al., 2008; Decesari et al., 2007). A primary mode of HULIS formation could derive from the incomplete breakdown of polymeric carbohydrates and lignin which can be further modified in the process of combustion. HULIS formation can also be secondary in nature, resulting from the transformation of pyrogenic semi-volatile organic compounds through condensation reactions with other molecules (Mayol-Bracero et al., 2002). Hoffer et al. (2004) and Gelencsér et al. (2003) also showed that HULIS may be produced in cloud droplets from aromatic acid precursors which may originate from biomass burning. Finally, Decesari et al. (2002) proposed that HULIS can derive from the reaction of soot particles with atmospheric oxidants. In this case, reactions with ozone can lead to the degradation of aromatic structures and to the formation of carbonyl and carboxyl functional groups (Bloss et al., 2005).

$\mathrm{K}_{\text {ndust }}^{+}$is considered a reliable tracer for biomass burning (Pio et al., 2008), but must be cautiously evaluated as $\mathrm{K}^{+}$also has terrestrial and marine sources. In Grenoble and Chamonix, we considered the marine source as negligible and evaluated the terrestrial contribution from the measured $\mathrm{Ca}^{2+}$ concentrations by applying to them an average
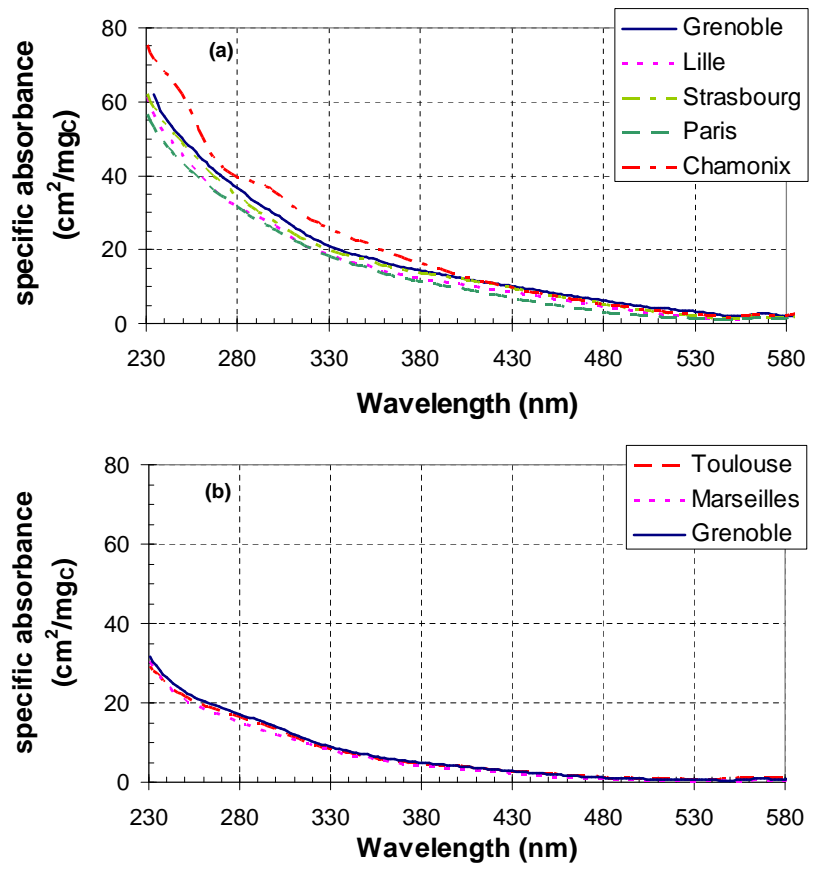

Fig. 2. Typical absorption spectra for HULIS ${ }_{W S}$ for each city. (a) Winter cities, (b) summer cities. 


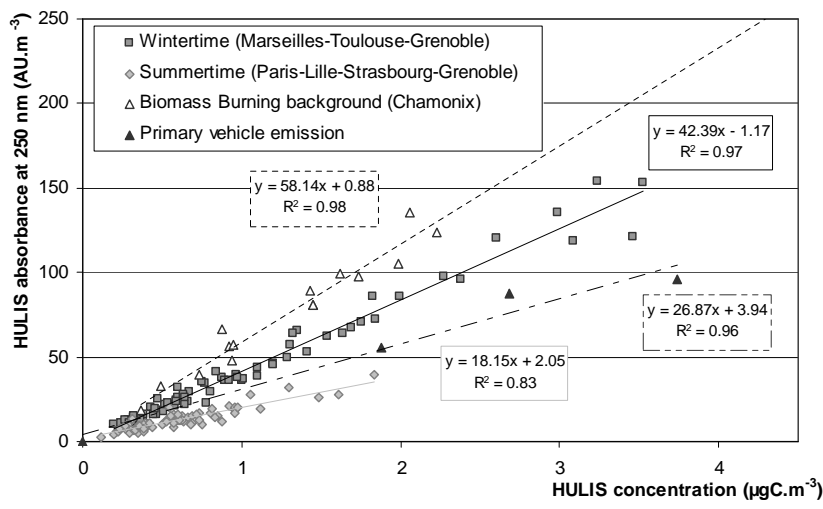

Fig. 3. Correlations between HULIS carbon concentration $\left(\mu \mathrm{gC} \mathrm{m}^{-3}\right)$ and UV HULIS absorbance at $250 \mathrm{~nm}$ (Arbitrary Unit per cube meter). Atmospheric HULIS data coming from different French cities are gathered by seasons. HULIS coming from Chamonix (biomass burning background) are not mix with other winter sample set.

$\left(\mathrm{K}^{+} / \mathrm{Ca}^{2+}\right)_{\text {dust }}$ ratio. This average ratio was estimated from a linear regression of the summer's ion concentrations in Grenoble. The observed correlation $\left(r^{2}=0.58,20\right.$ points) yields $\left(\mathrm{K}^{+} / \mathrm{Ca}^{2+}\right)_{\text {dust }}=0.11$; this value is close to 0.12 the value adopted by Puxbaum et al. (2007) based on measured concentrations from summer aerosol at three European continental sites in summer. In Strasbourg and Paris, we applied the same $\left(\mathrm{K}^{+} / \mathrm{Ca}^{2+}\right)_{\text {dust }}=0.11$, resulting in a correction that did not exceed $14 \%$ in Strasbourg and reached up to $50 \%$ (average $28 \%$ ) in Paris. Lille could not be corrected in the same way, as potassium also has a marine source that would have to be accounted for, which was not possible due to the very high blank values for sodium on the quartz filter (see Sect. 2.2). The observed correlations between estimated $\mathrm{K}_{\text {ndust }}^{+}$and HULIS $\mathrm{WS}$ are summarized in Table 3. They are very clear for all 4 cities. Moreover, for Paris, Strasbourg and Lille, independent measurements of Levoglucosan, another tracer for biomass burning, also show very clear correlations between HULIS ${ }_{\mathrm{WS}}$ and the tracer (Pissot et al., 2010). Such correlations do not necessarily mean common sources, especially in winter, when temperature inversions are common and can induce co-varying concentrations of any sources blocked under the inversion. In order to exclude this hypothesis, we looked into the correlation between HULIS WS $_{\text {and }}$ EC, as a representative primary urban emission. EC and HULIS ${ }_{W S}$ are not related (Table 3), thus excluding a meteorologically induced correlation between $\mathrm{K}_{\text {ndust }}^{+}$and HULIS ${ }_{\mathrm{WS}}$, and indicating different sources for $\mathrm{EC}$ and HULIS ${ }_{W S}$. EC is produced by combustion sources, which in urban settings in winter are mainly fossil fuel combustion and biomass burning in the form of residential wood burning. It has been shown in Göteborg (Szidat et al., 2009) and Zurich (Szidat et al., 2006) that fossil fuel combustion contribute for 75 to $90 \%$ of EC, leaving biomass burning as a minor source for EC. The non correlation of HULISWS with $\mathrm{EC}$, together with the clear correlation observed with $\mathrm{K}_{\text {ndust }}^{+}$ thus indicates that wood combustion is probably the main source of HULIS ${ }_{W S}$ in the large French cities studied during winter. In the mid seasons in Grenoble, the correlation between HULIS ${ }_{W S}$ and $\mathrm{K}_{\text {ndust }}^{+}$gets weaker $\left(r^{2}=0.49\right)$ although with a very similar slope (4.57). In the same time, the correlation with EC completely disappears $\left(r^{2}=0.05\right)$. This agrees with a shift between summer and winter sources.

Yet, HULIS ${ }_{W S}$ collected in Chamonix present a stronger absorbance than those collected in winter in other cities (Table 2 and Fig. 3) while we know that a very large fraction of the PM at this site is due to local emissions of wood combustion from domestic heating (Marchand et al., 2004). Measurements of $\mathrm{NO}$ and $\mathrm{O}_{3}$ near the sampling site are available from the local Air Quality Monitoring Network, and indicate average values of $116 \pm 93$ and $4 \pm 2 \mu \mathrm{g} \mathrm{m}^{-3}$ respectively. This is a typical situation where $\mathrm{O}_{3}$ is titrated by local traffic emissions of NO, under very stagnant conditions in a deep Alpine valley: Chamonix lies at $1500 \mathrm{~m}$ a.s.l., surrounded by mountains up to $4800 \mathrm{~m}$ (Mont Blanc). The same data are available in the other cities, and the situation is nowhere as dramatic as in Chamonix with typical concentrations for ozone around $20-50 \mathrm{\mu g} \mathrm{m}^{-3}$, indicating a much less stagnant situation on average. This would mean that the Chamonix aerosol can be regarded as unaffected yet by ozone chemical ageing. As reaction with ozone tends to destroy double bonds, it would reduce the specific absorbance of HULIS ${ }_{W S}$ and their E2/E3 ratio, which would agree with our observation of a higher specific absorbance at $250 \mathrm{~nm}$ and higher

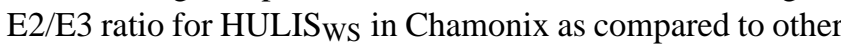
French cities. Further investigations on this point are in progress, with direct measurements of HULIS ${ }_{W S}$ fractions and characteristics from samples collected at the emission from different sources of biomass burning.

\subsubsection{Summer}

Summer HULIS ${ }_{W S}$ present a lower specific absorbance at all wavelength and a higher E2/E3 ratio, an indication of a more pronounced aliphatic character (Fig. 2). Such structures may belong to secondary products from some biogenic or anthropogenic sources. Decesari et al. (2007) suggested secondary atmospheric oxidation processes as possible sources for atmospheric WSOC in an urban area in summer. This last study also showed that the composition of biogenic and anthropogenic secondary organic aerosol (SOA) are characterized by a high content of aliphatic structures (high $\mathrm{H}-\mathrm{C}$ and $\mathrm{H}-\mathrm{C}-\mathrm{O}$ content) and a systematic low aromatic content. Recent studies using ${ }^{1} \mathrm{H}-\mathrm{NMR}$ have shown that prolonged ageing of SOA leads to a reduction of hydroxyl and aromatic groups (Moretti et al., 2008). Numerous investigations have confirmed the existence of polymeric/oligomeric compounds with molecular masses up to $1600 \mathrm{Da}$ in various SOA formed from photooxidation of both anthropogenic (Gross et 
Table 3. Correlations observed in winter between $\operatorname{HULIS}_{\mathrm{WS}}\left(y ; \mu \mathrm{g} \mathrm{C} \mathrm{m}^{-3}\right)$ and $\mathrm{K}_{\text {ndust }}^{+}\left(x ; \mu \mathrm{g} \mathrm{m}^{-3}\right)$, and between HULIS $\mathrm{WS}\left(y ; \mu \mathrm{g} \mathrm{C} \mathrm{m}{ }^{-3}\right)$ and $\mathrm{EC}\left(x ; \mu \mathrm{g} \mathrm{m}^{-3}\right)$.

\begin{tabular}{llll}
\hline $\begin{array}{l}\text { Location and } \\
\text { sampling month }\end{array}$ & $\begin{array}{l}\text { Number of } \\
\text { samples }\end{array}$ & $\mathrm{K}_{\text {ndust }}^{+}$ & $\mathrm{EC}$ \\
\hline $\begin{array}{l}\text { Paris 08 } \\
\text { January to March }\end{array}$ & 16 & $y=15 x-0.12\left(r^{2}=0.74\right)$ & $y=1.62 x-0.03\left(r^{2}=0.26\right)$ \\
$\begin{array}{l}\text { Strasbourg 08 } \\
\text { January to March }\end{array}$ & 16 & $y=6 x+0.11\left(r^{2}=0.81\right)$ & $y=3.35 x+0.22\left(r^{2}=0.34\right)$ \\
$\begin{array}{l}\text { Grenoble 08 } \\
\text { January to March }\end{array}$ & 9 & $y=5.5 x+0.34\left(r^{2}=0.87\right)$ & $y=0.38 x+0.59\left(r^{2}=0.49\right)$ \\
$\begin{array}{l}\text { Chamonix 07 } \\
\text { December }\end{array}$ & 16 & $y=4.3 x+0.23\left(r^{2}=0.77\right)$ & $y=0.14 x+0.71\left(r^{2}=0.40\right)$ \\
\end{tabular}

al., 2006; Wyche et al., 2009) and biogenic (Surratt et al., 2006; Tolocka et al., 2004) precursors in simulation chamber studies. Such polymeric products present spectral properties similar to HULIS in atmospheric aerosols (Limbeck et al., 2003), despite the fact that the majority of HULIS compounds seem to be in the range of 400-700 Da (Graber and Rudich, 2006). During warmer periods in urban site, maximum molecular weight of the HULIS determined with Size Exclusion Chromatography coupled to UV detection had shown positive correlations with temperature and ozone. Theses results suggest photochemical processes as a source of secondary HULIS (Samburova et al., 2005). Soot oxidation by ozone has also been suggested as a secondary source of HULIS (Decesari et al., 2002), where aromatic structures are degraded, leading to the formation of carbonyl and carboxylic functional groups (Bloss et al., 2005). Such oxidation processes leading to HULIS by aerosol ageing can also be initiated by $\mathrm{OH}$ and $\mathrm{NO}_{3}$ radicals, or by soluble oxidants such as $\mathrm{H}_{2} \mathrm{O}_{2}$, organic peracids and organic peroxides (Jammoul et al., 2008; Vione et al., 2006). As a consequence, in urban environments, HULIS can both be secondarily formed by chemical reactions from various precursors and directly emitted into the atmosphere by fossil fuel combustion. Our data show that ambient HULIS ${ }_{W S}$ in summer exhibit a lower specific absorbance than HULIS ${ }_{W S}$ representative of the primary automobile emission source. This could be viewed as a mixing process between this primary source and secondarily produced HULIS ${ }_{W S}$ exhibiting a much lower specific absorbance. Correlation between EC and HULISWS (Table 3) is very poor in summer, which indicates that fossil fuel combustion is actually not an influential source of HULISWS in summer. On the opposite, we found very good correlations between oxalic acid and HULIS ${ }_{W S}$ in summer on all our sites (Table 3). Although the sources of oxalic acid are not extremely well known, especially in urban environments, it is thought to be mainly secondary (Legrand et al., 2007, and references therein) and we thus see the observed correlation as an indication of the probable secondary origin of HULIS $_{W S}$ in our urban sampling sites. Together with the observation that the measured urban HULIS $_{W S}$ in summer have a lower absorbance than those measured in our tunnel experiment, this would indicate that the secondarily formed HULIS $_{W S}$ have indeed the lowest specific absorbance, which would indicate mainly a low aromaticity content. This would agree with the mechanism invoked for pyruvic acid photoinduced oligomerization, that mainly forms aliphatic polymeric structures (Guzman et al., 2006).

\subsubsection{SRFA and use of specific absorbance}

Suwannee River Fulvic Acid (SRFA) (IHSS, 15101F) is mainly used in the literature as a model compound for atmospheric HULIS ${ }_{W S}$ for different types of experiments (Baduel et al., 2009). However, it is hypothesized that HULISWs show structural differences with aquatic humic substances, like a higher aliphatic structure and a lower degree of oxidation (Graber and Rudich, 2006). A data set for SRFA was obtained in our study for measurements on the same standard solution, for a range of carbon masses between 0 and $20 \mu \mathrm{g}$. Figure 4 indicates that this standard compound presents a specific absorbance at $250 \mathrm{~nm}$ close to that of the samples collected in urban areas in winter, with a slightly lower value compared to that obtained for the data set from the Alpine valley in Chamonix. Conversely, characteristics of HULIS ${ }_{W S}$ collected in summer may largely differ from that of SRFA, with a much lower absorbance at $250 \mathrm{~nm}$ for the former. Therefore, it is not appropriate to consider SRFA as a representative standard for the whole HULIS ${ }_{W S}$ fraction. Absolute calibration of UV absorbance with SRFA can not be used for quantification of HULIS ${ }_{W S}$ because it can overestimate the carbon content of HULIS by a factor of 3 . 
Table 4. Correlations observed in summer between $\operatorname{HULIS}_{\mathrm{WS}}\left(y ; \mu \mathrm{g} \mathrm{C \textrm {m } ^ { - 3 }}\right)$ and oxalic acid $\left(x ; \mu \mathrm{g} \mathrm{m}^{-3}\right)$, and between HULIS $\mathrm{WS}(y$; $\left.\mu \mathrm{g} \mathrm{C} \mathrm{m}{ }^{-3}\right)$ and $\mathrm{EC}\left(x ; \mu \mathrm{g} \mathrm{m}^{-3}\right)$.

\begin{tabular}{llll}
\hline $\begin{array}{l}\text { Location and } \\
\text { sampling month }\end{array}$ & $\begin{array}{l}\text { Number of } \\
\text { samples }\end{array}$ & $\begin{array}{l}\text { Oxalic } \\
\text { acid }\end{array}$ & EC \\
\hline $\begin{array}{l}\text { Marseilles 08 } \\
\text { July }\end{array}$ & 16 & $y=5.4 x+0.20\left(r^{2}=0.77\right)$ & $y=0.35 x-0.10\left(r^{2}=0.48\right)$ \\
$\begin{array}{l}\text { Toulouse 08 } \\
\text { June to August }\end{array}$ & 10 & $y=4.2 x-0.10\left(r^{2}=0.72\right)$ & $y=0.22 x+0.26\left(r^{2}=0.18\right)$ \\
$\begin{array}{l}\text { Grenoble 08 } \\
\text { May to August }\end{array}$ & 16 & $y=4.2 x+0.23\left(r^{2}=0.72\right)$ & $y=0.40 x+0.08\left(r^{2}=0.38\right)$ \\
& & & \\
\hline
\end{tabular}

However, UV absorption could be a useful and rapid indicator of the origin of HULIS ${ }_{W S}$ in atmospheric samples. Figure 4 presents specific absorbance in our samples as a function of the time of year. Average values of 22.6 \pm 4.5 in summer and $42.3 \pm 6.0$ in winter were observed. Relative standard deviation represent about $15-20 \%$ in summer and $10-15 \%$ in winter, much lower than the relative seasonal variation. We can conclude that this measurement is useful to give a good idea of the formation processes of the HULISWS fractions.

The seasonal cycle for specific absorbance of HULIS ${ }_{W S}$ has only been observed in Grenoble. Yet, because the sources inferred in summer (secondary production) and in winter (residential wood burning) in each subset of cities (Lille, Strasbourg, Grenoble, Paris and Chamonix in winter; Grenoble, Toulouse and Marseille in summer) are very seasonal and ubiquitous, we argue that the seasonal cycle observed in Grenoble is most probably valid in the other cities as well.

\section{Conclusions}

Organic aerosol concentrations have been monitored in six different French cities during winter and summer. Watersoluble HULIS comprises about $23-43 \%$ of WSOC and 13$23 \%$ of OC in different urban environments. The HULIS contribution is significant indicating the global importance of HULIS in controlling the mass concentration of organic aerosol.

Specific absorbance at 250, 272, 280 and $300 \mathrm{~nm}$ was used to investigate structural differences in HULIS ${ }_{W S}$ as a function of sampling site and season. Specific absorbance does not significantly change from one city to another for a given time period, but depends strongly on the season. The only exception is Chamonix in winter, wher HULIS WS $_{\text {S }}$ present a higher specific absorbance compared to other cities. This is tentatively attributed to suppressed ageing because of ozone titration by NO in stagnant air of a deep alpine valley, leading us to argue that ageing causes a decrease

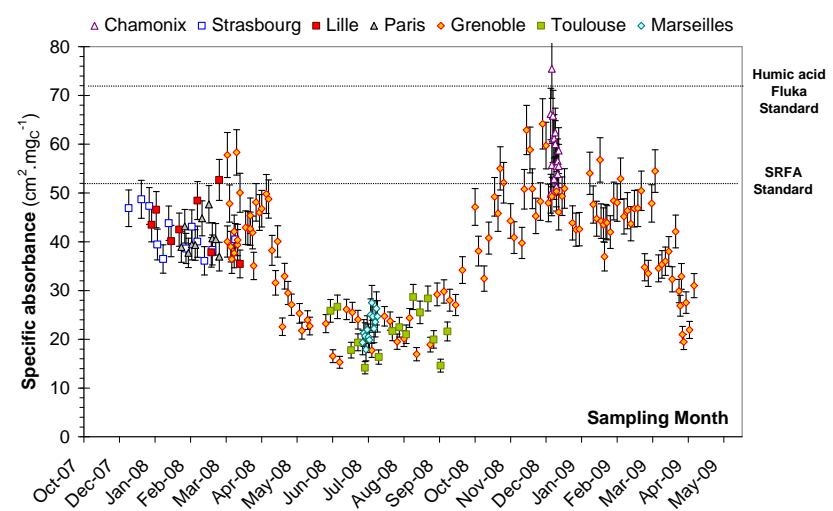

Fig. 4. Specific absorbance at $250 \mathrm{~nm}$ of HULIS from atmospheric aerosol samples depending on sampling season and environment. Also shown are the specific absorbance at the same wavelength for two popular reference Fulvic and Humic acids.

of specific absorbance for HULISWs. Summer HULIS ${ }_{W S}$ exhibit a lower specific absorbance, characteristic of more aliphatic/less aromatic structures. Those seasonal differences are more significant than any intra-seasonnal or geographic variability, which points to formation processes or sources largely independent of the local emissions. Indeed, strong correlations with $\mathrm{K}_{\text {ndust }}^{+}$in winter suggest residential wood burning as the main source for HULIS ${ }_{W S}$ in winter; and strong correlations with oxalic acid in summer points towards secondary production as the probable source of HULISWS in summer. As these sources are ubiquitous, we hypothesize that although it has strictly been observed only in Grenoble, the seasonal cycle in specific absorbance, driven by a source change from wood burning in winter to secondary production in summer, is a common feature of most urban environments. 
Acknowledgements. This work is supported by ADEME, INSU, LEFE CHAT and the French Ministère de l'Ecologie, de l'Energie, du Développement durable et de l'Aménagement du Territoire. We would like to thank AIRPARIF, Atmo Nord Pas de Calais, Atmo Rhône-Alpes GIE/ASCOPARG, ASPA and N. Marchand for the sample collection. Many warm thanks to Eva Leoz-Garziandia (INERIS) for coordinating the year-long study in the cities. We are grateful to N. Pissot, J. L. Besombes (LCME) and J. Claveau for their help in this work as well as to both anonymous reviewers whose suggestions helped greatly improve our manuscript.

Edited by: A. Nenes

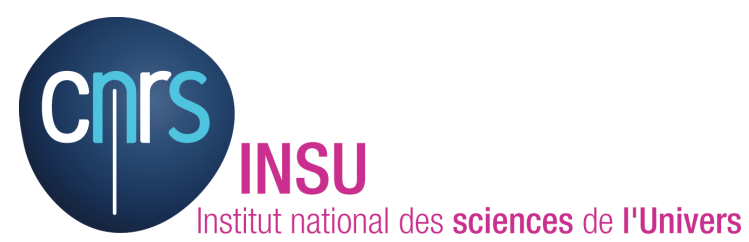

The publication of this article is financed by CNRS-INSU.

\section{References}

Asa-Awuku, A., Sullivan, A. P., Hennigan, C. J., Weber, R. J., and Nenes, A.: Investigation of molar volume and surfactant characteristics of water-soluble organic compounds in biomass burning aerosol, Atmos. Chem. Phys., 8, 799-812, 2008,

http://www.atmos-chem-phys.net/8/799/2008/.

Aymoz, G., Jaffrezo, J. L., Chapuis, D., Cozic, J., and Maenhaut, W.: Seasonal variation of $\mathrm{PM}_{10}$ main constituents in two valleys of the French Alps. I: EC/OC fractions, Atmos. Chem. Phys., 7, 661-675, 2007, http://www.atmos-chem-phys.net/7/661/2007/.

Baduel, C., Voisin, D., and Jaffrezo, J. L.: Comparison of analytical methods for Humic Like Substances (HULIS) measurements in atmospheric particles, Atmos. Chem. Phys., 9, 5949-5962, 2009, http://www.atmos-chem-phys.net/9/5949/2009/.

Bloss, C., Wagner, V., Jenkin, M. E., Volkamer, R., Bloss, W. J., Lee, J. D., Heard, D. E., Wirtz, K., Martin-Reviejo, M., Rea, G., Wenger, J. C., and Pilling, M. J.: Development of a detailed chemical mechanism (MCMv3.1) for the atmospheric oxidation of aromatic hydrocarbons, Atmos. Chem. Phys., 5, 641664,2005 ,

http://www.atmos-chem-phys.net/5/641/2005/.

Cavalli, F., Viana, M., Yttri, K. E., Genberg, J., and Putaud, J.-P.: Toward a standardised thermal-optical protocol for measuring atmospheric organic and elemental carbon: the EUSAAR protocol, Atmos. Meas. Tech., 3, 79-89, 2010,

http://www.atmos-meas-tech.net/3/79/2010/.

Chin, Y., Aiken, G., and O'Loughlin, E.: Molecular Weight, Polydispersity, and Spectroscopic Properties of Aquatic Humic Substances, Environ. Sci. Technol., 28(11), 1853-1858, doi:10.1021/es00060a015, 1994.

Decesari, S., Facchini, M. C., Matta, E., Lettini, F., Mircea, M., Fuzzi, S., Tagliavini, E., and Putaud, J. -P.: Chemical features and seasonal variation of fine aerosol water-soluble organic com- pounds in the Po Valley, Italy, Atmos. Environ., 35(21), 36913699, doi:10.1016/S1352-2310(00)00509-4, 2001.

Decesari, S., Facchini, M. C., Matta, E., Mircea, M., Fuzzi, S., Chughtai, A. R., and Smith, D. M.: Water soluble organic compounds formed by oxidation of soot, Atmos. Environ., 36(11), 1827-1832, doi:10.1016/S1352-2310(02)00141-3, 2002.

Decesari, S., Mircea, M., Cavalli, F., Fuzzi, S., Moretti, F., Tagliavini, E., and Facchini, M. C.: Source Attribution of Water-Soluble Organic Aerosol by Nuclear Magnetic Resonance Spectroscopy, Environ. Sci. Technol., 41(7), 2479-2484, doi:10.1021/es0617111, 2007.

Dinar, E., Riziq, A. A., Spindler, C., Erlick, C., Kiss, G., and Rudich, Y.: The complex refractive index of atmospheric and model humic-like substances (HULIS) retrieved by a cavity ring down aerosol spectrometer (CRD-AS), Faraday Discuss., 137, 279-295, 2008.

Dinar, E., Taraniuk, I., Graber, E. R., Katsman, S., Moise, T., Anttila, T., Mentel, T. F., and Rudich, Y.: Cloud Condensation Nuclei properties of model and atmospheric HULIS, Atmos. Chem. Phys., 6, 2465-2482, 2006, http://www.atmos-chem-phys.net/6/2465/2006/.

Duarte, R. M., Pio, C. A., and Duarte, A. C.: Spectroscopic study of the water-soluble organic matter isolated from atmospheric aerosols collected under different atmospheric conditions, Anal. Chim. Acta, 530(1), 7-14, 2005.

Duarte, R. M. B. O., Silva, A. M. S., and Duarte, A. C.: TwoDimensional NMR Studies of Water-Soluble Organic Matter in Atmospheric Aerosols, Environ. Sci. Technol., 42(22), 82248230, doi:10.1021/es801298s, 2008.

Duarte, R. M., Santos, E. B., Pio, C. A., and Duarte, A. C.: Comparison of structural features of water-soluble organic matter from atmospheric aerosols with those of aquatic humic substances, Atmos. Environ., 41(37), 8100-8113, doi:10.1016/j.atmosenv.2007.06.034, 2007.

El Haddad, I., Marchand, N., Dron, J., Temime-Roussel, B., Quivet, E., Wortham, H., Jaffrezo, J. L., Baduel, C., Voisin, D., Besombes, J. L., and Gille, G.: Comprehensive primary particulate organic characterization of vehicular exhaust emissions in France, Atmos. Environ., 43(39), 6190-6198, doi:10.1016/j.atmosenv.2009.09.001, 2009.

Feczko, T., Puxbaum, H., Kasper-Giebl, A., Handler, M., Limbeck, A., Gelencsér, A., Pio, C., Preunkert, S., and Legrand, M.: Determination of water and alkaline extractable atmospheric humic-like substances with the TU Vienna HULIS analyzer in samples from six background sites in Europe, J. Geophys. Res., 112(D23), D23S10, doi:10.1029/2006JD008331, 2007.

Gelencsér, A., Hoffer, A., Kiss, G., Tombácz, E., Kurdi, R., and Bencze, L.: In-situ Formation of Light-Absorbing Organic Matter in Cloud Water, J. Atmos. Chem., 45(1), 25-33, doi:10.1023/A:1024060428172, 2003.

Graber, E. R. and Rudich, Y.: Atmospheric HULIS: How humiclike are they? A comprehensive and critical review, Atmos. Chem. Phys., 6, 729-753, 2006,

http://www.atmos-chem-phys.net/6/729/2006/.

Graham, B., Mayol-Bracero, O., Guyon, P., Roberts, G., Decesari, S., Facchini, M. C., Artaxo, P., Maenhaut, W., Köll, P., and Andreae, M.: Water-soluble organic compounds in biomass burning aerosols over Amazonia1. Characterization by NMR and GC-MS, J. Geophys. Res., 107(D20), 8047, 
doi:10.1029/2001JD000336, 2002.

Gross, D. S., Galli, M. E., Kalberer, M., Prevot, A. S. H., Dommen, J., Alfarra, M. R., Duplissy, J., Gaeggeler, K., Gascho, A., Metzger, A., and Baltensperger, U.: Real-Time Measurement of Oligomeric Species in Secondary Organic Aerosol with the Aerosol Time-of-Flight Mass Spectrometer, Anal. Chem., 78(7), 2130-2137, doi:10.1021/ac0601381, 2006.

Guzman, M. I., Colussi, A. J., and Hoffmann, M. R.: Photoinduced Oligomerization of Aqueous Pyruvic Acid, J. Phys. Chem. A, 110(10), 3619-3626, doi:10.1021/jp056097z, 2006.

Hatch, C., Gierlus, K., Schuttlefield, J., and Grassian, V.: Water adsorption and cloud condensation nuclei activity of calcite and calcite coated with model humic and fulvic acids, Atmos. Environ., 42(22), 5672-5684, doi:10.1016/j.atmosenv.2008.03.005, 2008.

Hautala, K., Peuravuori, J., and Pihlaja, K.: Measurement of aquatic humus content by spectroscopic analyses, Water Research, 34(1), 246-258, doi:10.1016/S0043-1354(99)00137-2, 2000.

Hoffer, A., Kiss, G., Blazso, M., and Gelencsér, A.: Chemical characterization of humic-like substances (HULIS) formed from a lignin-type precursor in model cloud water, Geophys. Res. Lett., 31(6), L06115, doi:10.1029/2003GL018962, 2004.

Jammoul, A., Gligorovski, S., George, C., and D'Anna, B.: Photosensitized Heterogeneous Chemistry of Ozone on Organic Films, J. Phys. Chem. A, 112(6), 1268-1276, doi:10.1021/jp074348t, 2008.

Kiss, G., Varga, B., Galambos, I., and Ganszky, I.: Characterization of water-soluble organic matter isolated from atmospheric fine aerosol, J. Geophys. Res., 107(D21), 8339, doi:10.1029/2001JD000603, 2002.

Krivácsy, Z., Kiss, G., Ceburnis, D., Jennings, G., Maenhaut, W., Salma, I., and Shooter, D.: Study of water-soluble atmospheric humic matter in urban and marine environments, Atmos. Res., 87(1), 1-12, doi:10.1016/j.atmosres.2007.04.005, 2008.

Legrand, M., Preunkert, S., Oliveira, T., Pio, C. A., Hammer, S., Gelencsér, A., Kasper-Giebl, A., and Laj, P.: Origin of C2-C5 dicarboxylic acids in the European atmosphere inferred from yearround aerosol study conducted at a west-east transect, J. Geophys. Res., 112, D23S07 doi:10.1029/2006JD008019, 2007.

Li, A., Hu, J., Li, W., Zhang, W., and Wang, X.: Polarity based fractionation of fulvic acids, Chemosphere, 77(10), 1419-1426, doi:10.1016/j.chemosphere.2009.09.002, 2009.

Limbeck, A., Handler, M., Neuberger, B., Klatzer, B., and Puxbaum, H.: Carbon-Specific Analysis of Humic-like Substances in Atmospheric Aerosol and Precipitation Samples, Anal. Chem., 77(22), 7288-7293, doi:10.1021/ac0509531, 2005.

Limbeck, A., Kulmala, M., and Puxbaum, H.: Secondary organic aerosol formation in the atmosphere via heterogeneous reaction of gaseous isoprene on acidic particles, Geophys. Res. Lett., 30(19), 1996, doi:10.1029/2003GL017738, 2003.

Marchand, N., Besombes, J. L., Chevron, N., Masclet, P., Aymoz, G., and Jaffrezo, J. L.: Polycyclic aromatic hydrocarbons (PAHs) in the atmospheres of two French alpine valleys: sources and temporal patterns, Atmos. Chem. Phys., 4, 1167-1181, 2004, http://www.atmos-chem-phys.net/4/1167/2004/.

Mayol-Bracero, O. L., Guyon, P., Graham, B., Roberts, G., Andreae, M., Decesari, S., Fuzzi, S., and Artaxo, P.: Water-soluble organic compounds in biomass burning aerosols over Amazonia 2. Apportionment of the chemical composition and importance of the polyacidic fraction, J. Geophys. Res., 107(D20), 8091, doi:10.1029/2001JD000522, 2002.

Moretti, F., Tagliavini, E., Decesari, S., Facchini, M. C., Rinaldi, M., and Fuzzi, S.: NMR Determination of Total Carbonyls and Carboxyls: A Tool for Tracing the Evolution of Atmospheric Oxidized Organic Aerosols, Environ. Sci. Technol., 42(13), 48444849, doi:10.1021/es703166v, 2008.

Peuravuori, J. and Pihlaja, K.: Molecular size distribution and spectroscopic properties of aquatic humic substances, Anal. Chim. Acta, 337(2), 133-149, doi:10.1016/S0003-2670(96)00412-6, 1997.

Pio, C., Legrand, M., Alves, C., Oliveira, T., Afonso, J., Caseiro, A., Puxbaum, H., Sanchez-Ochoa, A., and Gelencsér, A.: Chemical composition of atmospheric aerosols during the 2003 summer intense forest fire period, Atmos. Environ., 42(32), 7530-7543, doi:10.1016/j.atmosenv.2008.05.032, 2008.

Pissot, N., Besombes, J. L., Jaffrezo, J. L., Voisin, D., and Baduel, C.: Wood smoke impact on the ambient air quality of four large French cities using levoglucosan as principal biomass burning tracer, Atmos. Environ., in preparation, 2010.

Puxbaum, H., Caseiro, A., Sánchez-Ochoa, A., Kasper-Giebl, A., Claeys, M., Gelencsér, A., Legrand, M., Preunkert, S. and Pio, C.: Levoglucosan levels at background sites in Europe for assessing the impact of biomass combustion on the European aerosol background, J. Geophys. Res., 112, D23S05, doi:10.1029/2006JD008114, 2007.

Ricard, V., Jaffrezo, J. -L., Kerminen, V., Hillamo, R. E. J., Sillanpaa, M., Ruellan, S., Liousse, C., and Cachier, H.: Two years of continuous aerosol measurements in northern Finland, J. Geophys. Res., 107(D11), 4129, doi:10.1029/2001JD000952, 2002.

Salma, I., Ocskay, R., and Láng, G. G.: Properties of atmospheric humic-like substances water system, Atmos. Chem. Phys., 8, 2243-2254, 2008, http://www.atmos-chem-phys.net/8/2243/2008/.

Salma, I., Ocskay, R., Chi, X., and Maenhaut, W.: Sampling artefacts, concentration and chemical composition of fine watersoluble organic carbon and humic-like substances in a continental urban atmospheric environment, Atmos. Environ., 41(19), 4106-4118, doi:10.1016/j.atmosenv.2007.01.027, 2007.

Samburova, V., Zenobi, R., and Kalberer, M.: Characterization of high molecular weight compounds in urban atmospheric particles, Atmos. Chem. Phys., 5, 2163-2170, 2005, http://www.atmos-chem-phys.net/5/2163/2005/.

Sannigrahi, P., Sullivan, A. P., Weber, R. J., and Ingall, E. D.: Characterization of water-soluble organic carbon in urban atmospheric aerosols using solid-state 13C NMR spectroscopy, Environ. Sci. Technol., 40(3), 666-672, 2006.

Sullivan, A. P. and Weber, R. J.: Chemical characterization of the ambient organic aerosol soluble in water: 1. Isolation of hydrophobic and hydrophilic fractions with a XAD-8 resin, J. Geophys. Res., 111(9), D05314, doi:10.1029/2005JD006485, 2006.

Surratt, J. D., Murphy, S. M., Kroll, J. H., Ng, N. L., Hildebrandt, L., Sorooshian, A., Szmigielski, R., Vermeylen, R., Maenhaut, W., Claeys, M., Flagan, R. C., et al.: Chemical Composition of Secondary Organic Aerosol Formed from the Photooxidation of Isoprene, J. Phys. Chem. A, 110(31), 9665-9690, doi:10.1021/jp061734m, 2006.

Szidat, S., Ruff, M., Perron, N., Wacker, L., Synal, H.-A., Hallquist, M., Shannigrahi, A. S., Yttri, K. E., Dye, C., and Simpson, D.: 
Fossil and non-fossil sources of organic carbon (OC) and elemental carbon (EC) in Göteborg, Sweden, Atmos. Chem. Phys., 9, 1521-1535, 2009, http://www.atmos-chem-phys.net/9/1521/2009/.

Szidat, S., Jenk, T. M., Synal, H., Kalberer, M., Wacker, L., Hajdas, I., Kasper-Giebl, A., and Baltensperger, U.: Contributions of fossil fuel, biomass-burning, and biogenic emissions to carbonaceous aerosols in Zurich as traced by 14C, J. Geophys. Res., 111(D7), D07206, doi:10.1029/2005JD006590, 2006.

Tagliavini, E., Moretti, F., Decesari, S., Facchini, M. C., Fuzzi, S., and Maenhaut, W.: Functional group analysis by $\mathrm{H}$ $\mathrm{NMR} /$ chemical derivatization for the characterization of organic aerosol from the SMOCC field campaign, Atmos. Chem. Phys., 6, 1003-1019, 2006, http://www.atmos-chem-phys.net/6/1003/2006/.

Tolocka, M. P., Jang, M., Ginter, J. M., Cox, F. J., Kamens, R. M., and Johnston, M. V.: Formation of Oligomers in Secondary Organic Aerosol, Environ. Sci. Technol., 38(5), 14281434, doi:10.1021/es035030r, 2004.
Traina, S., Novak, J., and Smeck, N.: An Ultraviolet Absorbance Method of Estimating the Percent Aromatic Carbon Content of Humic Acids, J. Environ. Qual., 19(1), 151-153, 1990.

Vione, D., Maurino, V., Minero, C., Pelizzetti, E., Harrison, M. A. J., Olariu, R., and Arsene, C.: Photochemical reactions in the tropospheric aqueous phase and on particulate matter, Chem. Soc. Rev., 35(5), 441-453, 2006.

Wyche, K. P., Monks, P. S., Ellis, A. M., Cordell, R. L., Parker, A. E., Whyte, C., Metzger, A., Dommen, J., Duplissy, J., Prevot, A. S. H., Baltensperger, U., Rickard, A. R., and Wulfert, F.: Gas phase precursors to anthropogenic secondary organic aerosol: detailed observations of 1,3,5-trimethylbenzene photooxidation, Atmos. Chem. Phys., 9, 635-665, 2009, http://www.atmos-chem-phys.net/9/635/2009/. 